\title{
Penerapan Autoregressive Distributed Lag (ARDL) Dalam Memodelkan Pengaruh Indeks Harga Konsumen (IHK) Kelompok Bahan Makanan Dan Kelompok Makanan Jadi Terhadap Inflasi di Kota Palu
}

\section{An Application of Autoregressive Distributed Lag (ARDL) to The Consumer Price Index (CPI) Modeling Of Groceries and Finished Food Group That Affecting Inflation in Palu City}

\author{
Dewi Yuliastuti Tulak*), Junaidi, Iut Tri Utami \\ ${ }^{1}$ Jurusan Matematika Program Studi Statistika, Fakultas MIPA, Universitas Tadulako
}

\begin{abstract}
Inflation is an increasing process generally and continually which relates to market mechanisms. Inflation is one of the indicators which is used to measure stability process of goods circulation in the market. This indicator has an impact on the dynamics of economic growth. In this research, analysis of influence of consumer the index food priceand foods to the inflation rate in the Palu city is conducted. The Autoregressive Distributed Lag (ARDL) is a regression model using by incorporating the value of one variable that explains the value of the present time or value of the past of variable free as one of the regressor. The results indicate that there is no cointegration between variable and the model showing that the food prices influence the inflation in Palu city.
\end{abstract} Inflation.

Keywords: Autoregressive Distributed Lag, Cointegration, Consumer Price Index,

\begin{abstract}
ABSTRAK
Inflasi adalah suatu proses meningkatnya harga-harga secara umum dan terusmenerus berkaitan dengan mekanisme pasar. Inflasi merupakan salah satu indikator yang digunakan untuk mengukur stabilitas harga suatu barang di pasar. Indikator ini akan berdampak terhadap dinamika pertumbuhan ekonomi. Dalam penelitian ini, dilakukan analisis pengaruh indeks harga konsumen bahan makanan dan makanan jadi terhadap laju inflasi di kota Palu. Model yang digunakan adalah model Autoregressive Distributed Lag (ARDL) yaitu suatu model regresi dengan memasukkan nilai variabel yang menjelaskan nilai masa kini atau nilai masa lalu dari variable bebas sebagai salah satu variabel penjelas. Hasil penelitian ini menunjukkan bahwa tidak terdapat kointegrasi antar variabel dan model yang didapatkan yang menunjukkan bahwa harga bahan makanan berpengaruh terhadap inflasi di Kota Palu.
\end{abstract}

Kata kunci: Autoregresi Distribusi Lag, Kointegrasi, Indeks Harga Konsumen, Inflasi. 


\section{LATAR BELAKANG}

Indeks Harga Konsumen (IHK dapat diartikan sebagai indeks harga dari biaya sekumpulan barang konsumsi yang masing-masing diberi bobot menurut proporsi belanja masyarakat untuk komoditi yang bersangkutan. IHK mengukur harga sekumpulan barang tertentu (seperti bahan makanan pokok, sandang, perumahan, dan aneka barang dan jasa) yang dibeli konsumen. IHK ini juga lebih sering digunakan untuk menghitung inflasi karena IHK menghitung harga rata-rata dari barang dan jasa yang dikonsumsi oleh rumah tangga (BPS, 2016).

Inflasi didefinisikan sebagai suatu proses meningkatnya harga-harga secara umum dan terus-menerus (kontinu). Inflasi dapat disebabkan oleh dua hal, yaitu tarikan permintaan (kelebihan likuiditas/uang/alat tukar) dan tekanan produksi dan/atau distribusi (produksi dan/atau distribusi yang tidak mencukupi) (BPS, 2016).

Pengaruh IHK bahan makanan dan makanan jadi terhadap inflasi dapat diselidiki dengan menggunakan model regresi yang memasukkan nilai variabel yang menjelaskan nilai masa kini atau nilai masa lalu dari variabel bebas sebagai tambahan pada model yang memasukkan nilai lag dari variabel tak bebas sebagai salah satu variabel penjelas disebut Autoregressive Distributed Lag (ARDL) (Gujarati, 2014). Keistimewaan dari model autoregressive dan model distribusi lag adalah model tersebut membuat teori statis menjadi dinamis karena model regresi yang biasanya mengabaikan pengaruh waktu, melalui model autoregressive dan model distribusi lag, waktu ikut diperhitungkan dan panjang beda kala (lag) diketahui (Gujarati, 2014).

Pada penelitian yang dilakukan oleh Islamiyah (2012) didapatkan hasil yang menunjukkan bahwa tidak terdapat kointegrasi antar variabel dan model, hal ini menunjukkan bahwa variabel jumlah uang beredar berpengaruh signifikan terhadap harga minyak dunia dan inflasi. Ini berarti penerapan model Autoregressive Distributed Lag (ARDL) mampu memberi gambaran pemodelan yang baik. Hal inilah yang mendasari penulis untuk mengkaji penerapan model yang sama dengan kasus yang berbeda, yaitu pengaruh indeks harga konsumen bahan makanan dan makanan jadi terhadap inflasi di kota Palu.

\section{BAHAN DAN METODE}

Adapun bahan yang digunakan pada penelitian ini berupa data sekunder dari dua variabel indeks harga konsumen (IHK) yaitu kelompok bahan makanan 
dan kelompok makanan jadi. Data IHK disebut variabel bebas. Sedangkan data inflasi disebut variabel terikat, di mana kedua data tersebut yakni variabel IHK dan variabel inflasi diperoleh dari kantor Badan Pusat Statistik Provinsi Sulawesi Tengah. Data diambil dari tahun 2013 sampai tahun 2015.

Langkah awal yang dilakukan pada penelitian ini adalah melakukan plot pada masing-masing data lalu dilanjutkan dengan melakukan uji stasioneritas pada ragam dan rata-rata. Setelah itu, melakukan transformasi Box-Cox dan metode differenching pada data yang tidak stasioner. Setelah data telah stasioner, selanjutnya melakukan uji kointegrasi dengan menggunakan uji ADF (Augmented Dickey Fuller). Jika terjadi kointegrasi maka dilanjutkan dengan model Error Correction Model (ECM). Selanjutnya menentukan panjang lag optimal dengan meregresikan $Y_{t}$ pada masing-masing $X_{t}$. setelah itu menduga parameter model ARDL terhadap data yang telah di differenching jika data tidak stasioner. Lalu dilanjutkan dengan melakukan uji simultan dan uji parsial pada data. Setelah model ARDL didapatkan maka dilakukan interpretasi pada model.

\section{HASIL DAN PEMBAHASAN}

\section{Uji Stasioneritas}

Pengujian Stasioneritas bertujuan untuk melihat apakah data dari setiap variabel berada disekitar nilai rata-rata dengan fluktuasi yang tidak bergantung pada waktu dan varians. Sebelum melakukan uji stasioneritas, diperlukan plot data masing-masing variabel yang akan diuji untuk dilihat dan dianalisa terlebih dahulu (Maruddani, 2004). Uji stasioneritas bertujuan untuk melihat plot data Inflasi (Y), kelompok bahan makan $\left(\mathrm{X}_{1}\right)$ dan kelompok makanan jadi $\left(\mathrm{X}_{2}\right)$ apakah sudah berada pada sekitar ratarata atau belum.

Pada pengujian yang telah dilakukan (Gambar 1), untuk variabel inflasi telah stasioner karena sudah berada pada sekitar rata-rata dan menyebar seacara normal.

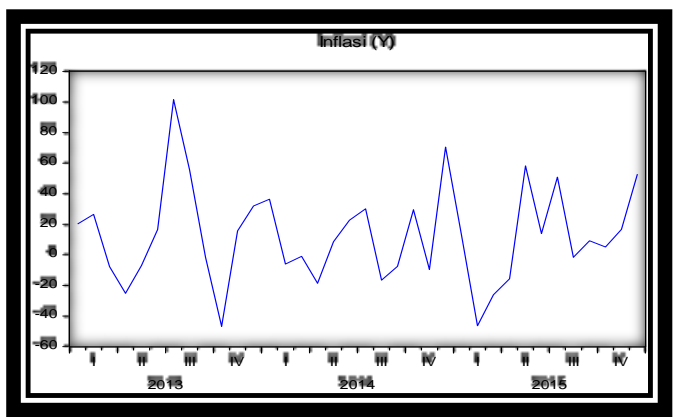

Gambar 1 Plot data inflasi

Sedangkan untuk variabel bahan makanan (Gambar 2) dan makanan jadi (Gambar 3), belum stasioner karena data tersebut tidak berada pada sekitar ratarata. Artinya terjadi fluktuasi yang cukup 
tajam pada bulan-bulan tertentu, sehingga perlu dilakukan penujian stasioneritas terhadap ragam dan rata-rata.

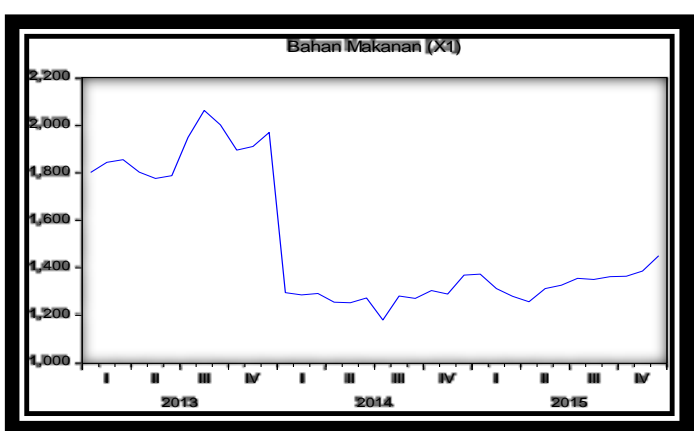

Gambar 2 Plot data Bahan makanan

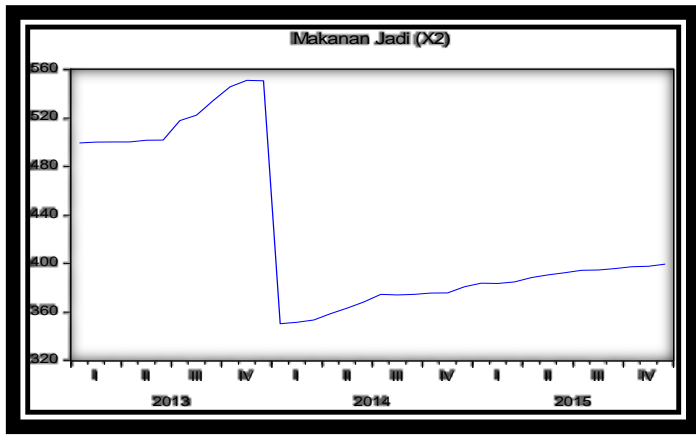

Gambar 3 Plot data makanan jadi

Uji yang digunakan untuk menguji stasioneritas data terhadap ragam adalah metode transformasi Box-Cox (Gambar 4) datanya dilihat apakah nilai $\lambda$ mendekati 1, Widhiarso (2010).

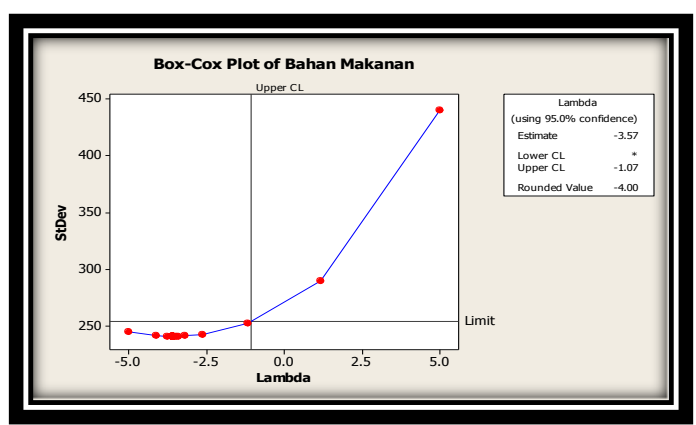

Gambar 4 Plot transformasi Box-Cox bahan makanan (pertama)

Dengan mengamati tabel lambda pada gambar tersebut, diperoleh nilai $\lambda=-3,57$ lebih kecil dari 1, sehingga perlu dilakukan transformasi Box-Cox kembali (Gambar 5).

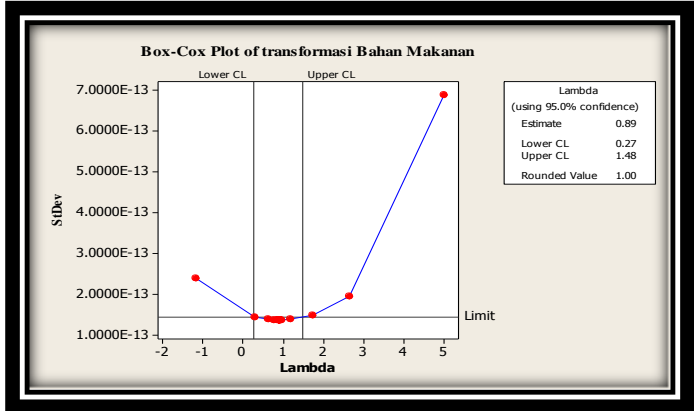

Gambar 5 Plot transformasi Box- Cox bahan makanan (kedua)

Setelah dilakukan transformasi Box-Cox kembali, didapatkan nilai $\lambda=0,89$ mendekati 1, sehingga tidak perlu di lakukan transformasi lagi untuk variabel bahan makanan karena data tersebut sudah stasioner terhadap ragam. Berikut disajikan scatterplot (Gambar 6) antara variabel inflasi dan bahan makanan pada $\lambda=1$.

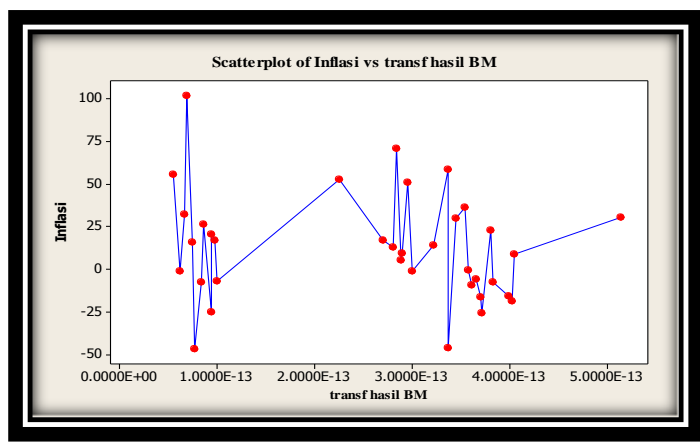

Gambar 6 Scatterplot bahan makanan terhadap inflasi

Sedangkan hasil transformasi Box Cox terhadap variabel makanan jadi menunjukkan bahwa data tidak stasioner terhadap ragam (Gambar 7) dan perlu ditransformasi kembali. 


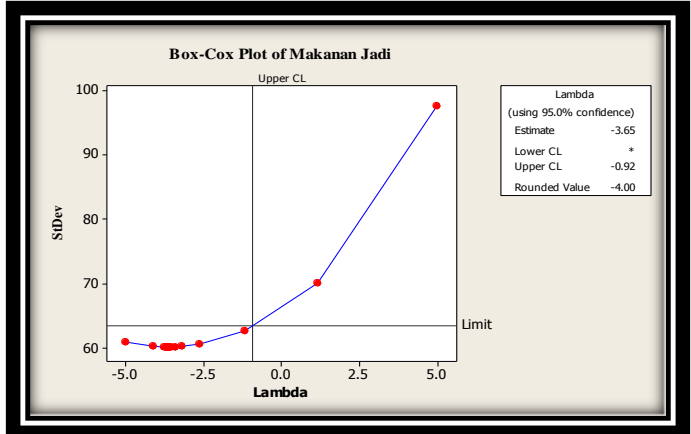

$\begin{array}{lllll}\text { Gambar } & 7 & \text { Plot } & \text { transformasi } & \text { Box-Cox }\end{array}$ makanan jadi (pertama)

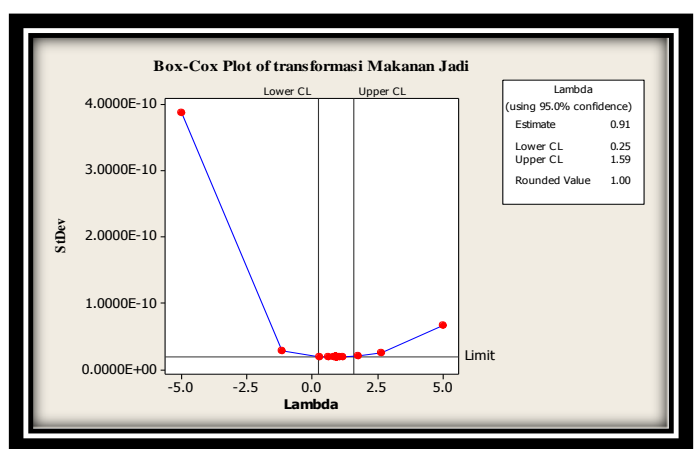

Gambar 8 Plot transformasi Box-Cox makanan jadi (kedua)

Setelah dilakukan transformasi Box-Cox kembali, (Gambar 8) diperoleh nilai $\lambda=$ 0.91 mendekati 1 sehingga tidak perlu dilakukan transformasi lagi untuk variabel makanan jadi. Untuk lebih meyakinkan lagi, berikut ditampilkan scatterplot antara variabel inflasi dan makanan jadi (Gambar 9).

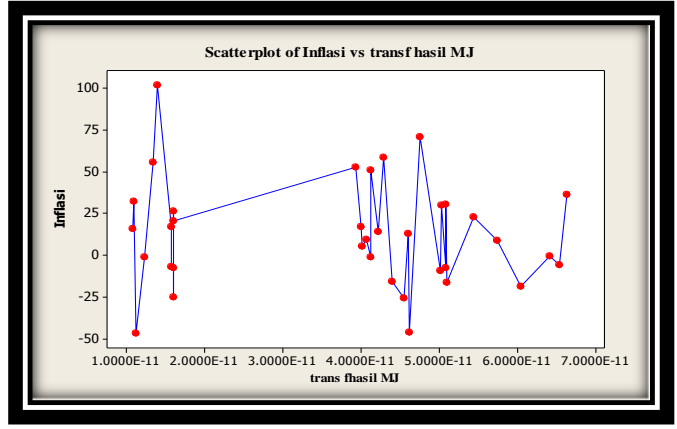

Gambar 9 Scatterplot makanan jadi terhadap inflasi

Pengujian stasioneritas terhadap rata-rata menggunakan uji akar unit dengan metode ADF (Augmented Dickey Fuller) test. Pada pengujian stasioneritas terhadap rata-rata pada variabel kelompok bahan makanan dan kelompok makanan jadi, masing-masing variabel belum stasioner pada level data, maka untuk mendapatkan data yang stasioner pada ratarata, digunakan fisrt difference (level pertama) pada data. Setelah dilakukan fisrt difference, nilai $\mathrm{ADF}$ test pada variabel kelompok bahan makanan (Tabel 1) dan kelompok makanan jadi (Tabel 2) lebih kecil dari nilai $\alpha$ dan nilai $p$-value 0,05 sehingga dapat disimpulkan bahwa kedua variabel sudah stasioner pada rata-rata. 
Tabel 1. Tabel ADF test bahan makanan pada level pertama (1st difference)

\begin{tabular}{|c|c|c|c|}
\hline & & t-Statistic & Prob.* \\
\hline \multicolumn{2}{|c|}{ Augmented Dickey-Fuller test statistic } & -5.947140 & 0.0000 \\
\hline Test critical values & $\begin{array}{c}1 \% \text { level } \\
5 \% \text { level } \\
10 \% \text { level }\end{array}$ & $\begin{array}{l}-3.639407 \\
-2.951125 \\
-2.614300\end{array}$ & \\
\hline
\end{tabular}

Tabel 2. Tabel ADF test makanan jadi pada level pertama (1st difference)

\begin{tabular}{|l|c|c|c|}
\hline \hline \hline & t-Statistic & Prob.* \\
\hline \hline Augmented Dickey-Fuller test statistic & & -5.660698 & 0.0000 \\
\hline Test critical values: & $1 \%$ level & -3.639407 & \\
& $5 \%$ level & -2.951125 & \\
& $10 \%$ level & -2.614300 & \\
\hline \hline
\end{tabular}

\section{Uji kointegrasi}

Berdasarkan hasil pengujian kointegrasi dengan menggunakan metode ADF test, telah diketahui bahwa variabel inflasi telah stasioner pada level data, sehingga memiliki ordo integrasi 0 atau $\mathrm{I}(0)$. Sedangkan untuk variabel kelompok bahan makanan dan kelompok bahan makanan jadi stasioner pada first difference, sehingga memiliki ordo integrase 1 atau $\mathrm{I}(1)$.

Sesuai dengan metode EngleGranger pada tahap 1 yang menyatakan bahwa jika variabel-variabel tersebut harus memiliki ordo yang sama, jika tidak sama berarti tidak terdapat kointegrasi antar vsriabel. Karena variabel inflasi, kelompok bahan makanan dan kelompok makanan jadi tidak memiliki ordo yang sama, maka dapat dinyatakan tidak terdapat kointegrasi antar variabel. Sehingga model yang cocok digunakan adalah model Autoregressive Distributed Lag (ARDL) pada data yang telah stasioner.

\section{Penentuan Panjang Lag}

Dengan menggunakan regresi linier pada masing-masing variabel, maka dapat ditentukan panjang lag optimal pada model ARDL.

Variabel inflasi diregresikan terhadap variabel inflasi sebulan sebelumnya, kemudian dilanjutkan dengan dua bulan sebelumnya, sampai koefisien berubah tanda dari negatif ke positif atau sebaliknya (Apriyanto, 2014).

Contoh:

$\mathrm{Y}=19.5+0.091 \mathrm{Y}_{\mathrm{t}-1}-0.190 \mathrm{Y}_{\mathrm{t}-2}-0.522 \mathrm{Y}_{\mathrm{t}-3}$ $\mathrm{Y}=23.9-0.032 \mathrm{Y}_{\mathrm{t}-1}-0.208 \mathrm{Y}_{\mathrm{t}-2}-0.508 \mathrm{Y}_{\mathrm{t}-3}-$ $0.193 \mathrm{Y}_{\mathrm{t}-4}$. 
Setelah dilakukan regresi linier pada masing-masing variabel, tanda dari masing-msing koefisien variabel berubah. Pada lag 0 sampai 2, semua koefisien pada variabel inflasi, kelompok bahan makanan dan kelompok makanan jadi bernilai positif. Sehingga di teruskan hingga lag 3 dan diperoleh perubahan tanda pada koefisien variabel inflasi yang berubah tanda menjadi negatif. Sedangkan koefisien variabel kelompok bahan makanan baru berubah tanda dari positif ke negatif pada lag 4, demikian pula koefisien variabel kelompok makanan jadi berubah dari negatif ke positif pada lag 4. Sehingga diperoleh panjang lag optimal untuk masing-masing variabel adalah: variabel inflasi mempunyai panjang lag 3 sedangkan variabel kelompok bahan makanan dan kelompok makanan jadi mempunya panjang lag 4 .

\section{Pemodelan Parameter dan Pengujian Parameter}

Model yang diperoleh pada penelitian ini adalah sebagai berikut:

$$
\mathrm{Y}=37,926+0.193 \mathrm{X}_{1}-0,741 \mathrm{X}_{2}
$$

Terdapat 2 macam pengujian parameter. Uji parameter simultan (F) dan uji parameter parsial (T). Pada pengujian simultan, diperoleh nilai $\mathrm{F}_{\text {hit }}$ sebesar 2,668 dan nilai $p$-value sebesar 0,084 dengan tingkat kepercayaan 95\%. Karena nilai $\mathrm{F}_{\text {hit }}>\mathrm{F}_{\mathrm{tab}}$, maka dapat disimpulkan bahwa variabel bebas $(\mathrm{X})$ telah mempengaruhi signifikansi variabel terikat $(\mathrm{Y})$. sedangkan untuk pengujian parsial, dengan tingkat kepercayaan 95\% diperoleh hasil dari masing-masing variabel yang memberikan kontribusi secara signifikan terhadap variabel terikat (INFLASI) adalah bahan makanan $\left(\mathrm{X}_{1}\right)$ dan makanan jadi $\left(\mathrm{X}_{2}\right)$. Sedangkan untuk pengujian secara parsial berdasarkan hasil output SPSS, di mana nilai $\mathrm{t}$ hitung variabel $X_{1}$ lebih besar dari pada nilai $t$ tabel $(2,258>1,692)$ dengan tingkat signifikan di bawah 0,05 yaitu 0,03 dan t hitung variabel $\mathrm{X}_{2}$ lebih kecil dari pada nilai $\mathrm{t}$ tabel $(-2,103<2,692)$ dengan tingkat signifikan dibawah 0,05 yaitu 0,04 .

Berdasarkan cara pengambilan keputusan uji parsial dalam analisis regresi dapat disimpulkan sebagai berikut:

- Variabel bahan makanan secara parsial berpengaruh signifikan terhadap laju inflasi kota Palu.

- Variabel makanan jadi secara parsial berpengaruh negatif terhadap laju inflasi kota Palu.

Setelah melakukan pengujian statistik asumsi klasik, diperoleh persamaan berikut: $\mathrm{Y}=37,926+0.193 \mathrm{X}_{1}$ - 0,741X $X_{2}$. Sehingga dapat disimpulkan bahwa kenaikan harga bahan makanan 
$\left(\mathrm{X}_{1}\right)$ sebesar $1 \%$ akan meningkatkan laju inflasi sebesar 0,193\%. Demikian pula pada makanan jadi, apabila harga makanan jadi meningkat sebesar $1 \%$, maka tingkat inflasi akan turun sebesar $0,741 \%$.

$\begin{array}{ccc} & \text { Saran bagi peneliti berikutnya } \\ \text { yang } & \text { tertarik dengan metode }\end{array}$ Autoregressive Distributed Lag (ARDL), diharapakan dapat menggunakan variabel penelitian yang lebih banyak, sehingga dapat memberikan hasil penelitian yang lebih baik. Apabila data penelitian pada variabel terikat dan variabel bebas tidak stasioner namun berkointegrasi, dapat menggunakan model Error Correction Model (ECM).

\section{UCAPAN TERIMA KASIH}

Terima kasih disampaikan kepada Badan Pusat Statistik (BPS) Provinsi Sulawesi Tengah yang telah menyediakan data.

\section{DAFTAR PUSTAKA}

Apriyanto, D. (2014). Penerapan Autoregressive Distributed Lag (ARDL) untuk pemodelan harga saham PT. Astra International TBK. Skripsi. Fakultas Matematika dan Ilmu Pengetahuan Alam, Universitas Brawijaya, Malang. http://statistik.studentjournal.ub.ac.i d/index.php/statistik/article/viewFile /183/203

[BPS] Badan Pusat Statistik. (2016). Indeks Harga Konsumen dan Inflasi Bulanan Indonesia. Diperoleh dari: https://data.go.id/dataset/inflasi-danihk. Diakses 3 November 2016.

Gujarati, D. (2014). Dasar-dasar ekonometrika. Solo: salemba empat.

Islamiyah, S. (2012). Penerapan Autoregressive Distributed Lag (ARDL) Dalam Memodelkan Pengaruh Harga Minyak Dunia Dan Jumlah Uang Beredar Terhadap Inflasi Di Indonesia. Skripsi. Fakultas Matematika dan Ilmu Pengetahuan Alam, Universitas Brawijaya, Malang. http://statistik.studentjournal.ub.ac.i d/index.php/statistik/article/view/12 $/ 12$.

Maruddani, D. A. I., (2004). Estimasi Parameter Model Regresi Non Stasioner dengan Variabel Dependen lag, studi kasus pada perkembangan ekspor Indonesia ke Jepang tahun 1980-2000. Skripsi. Jurusan Matematika, Fakultas Matematika dan Ilmu Pengetahuan Alam, Universitas Diponegoro, Semarang.

https://core.ac.uk/download/pdf/117 03465.pdf.

Widhiarso, W. (2010). Transformasi Ketidaknormalan Data Dengan Menggunakan Prosedur Box-Cox. Diperoleh dari: http://widhiarso.staff.ugm.ac.id/wp/ transformasi-ketidaknormalandistribusi-data-denganmenggunakan-prosedur-box-cox/. Diakses 20 April 2017. 